\title{
HNPCC (Lynch Syndrome): Differential Diagnosis, Molecular Genetics and Management - a Review
}

\author{
Henry T. Lynch', Jane F. Lynch', Trudy G. Shaw', Jan Lubiński \\ 'Department of Preventive Medicine and Public Health, 2500 California Plaza, Omaha NE 68178, USA; 'International Hereditary Cancer Center, ul. Połabska 4, 70 - \\ 115 Szzzecin, Poland
}

Key words: hereditary cancer, cancer genetics, colorectal cancer, Lynch syndrome

Corresponding author: Henry T. Lynch, Creighton University School of Medicine, 2500 California Plaza, 0maha NE 68178, USA. Phone: + 1402280 2942; fax: +1 402280 1734; e-mail: htlynch@creighton.edu

\begin{abstract}
HNPCC (Lynch syndrome) is the most common form of hereditary colorectal cancer (CRC), wherein it accounts for between 2-7 percent of the total CRC burden. When considering the large number of extracolonic cancers integral to the syndrome, namely carcinoma of the endometrium, ovary, stomach, hepatobiliary system, pancreas, small bowel, brain tumors, and upper uroepithelial tract, these estimates of its frequency are likely to be conservative. The diagnosis is based upon its natural history in concert with a comprehensive cancer family history inclusive of all anatomic sites. In order for surveillance and management to be effective and, indeed, lifesaving, among these high-risk patients, the linchpin to cancer control would be the physician, who must be knowledgeable about hereditary cancer syndromes, their molecular and medical genetics, genetic counseling, and, most importantly, the natural history of the disorders, so that the entirety of this knowledge can be melded to highly-targeted management.
\end{abstract}

\section{Introduction}

The annual worldwide incidence of colorectal cancer (CRC) is approximately 944,717 (males: 498,754; females: 445,963) and its worldwide mortality incidence is approximately 492,411 (males: 254,816; females: 237,595). In Poland, the annual incidence of CRC is approximately 13,327 (males: 6,916; females: 6,411) and its mortality is approximately 7,877 (males: 3,883; females: 3,994 ) [1]. The lifetime CRC risk in the general population is about $5-6 \%$ [2], but there is considerable racial and ethnic variation. For example, the lifetime CRC risk for Ashkenazi Jews ranges between $9 \%$ and 15\% [3].

The familial clustering of two or more first - and/or second-degree relatives with CRC constitutes approximately $20 \%$ of the total CRC burden, while a Mendelian inherited (monogenic) etiology for CRC accounts for approximately $5-10 \%$ of the total CRC burden. Among hereditary CRC-prone syndromes with multiple colonic polyps (adenomatous, juvenile, PeutzJeghers, mixed [hamartomatous, hyperplastic, adenomatous]), the best known, namely familial adenomatous polyposis (FAP), accounts for less than $1 \%$ of the total CRC burden, while the other syndromes in this group combine to account for another fraction of a percent of the total CRC incidence $[4,5]$. In contrast to those hereditary CRC disorders, hereditary nonpolyposis colorectal cancer (HNPCC), also known as Lynch syndrome, represents $2-7 \%$ of the total CRC burden [6]. Herein, the Lynch syndrome is the most common form of hereditary CRC.

Our purpose is to review the history, clinical, pathologic, and molecular genetic features of HNPCC (Lynch syndrome). Special attention will be given to its differential diagnosis and molecular genetics, in concert with state-of-the-art surveillance and management recommendations. 


\section{Important Clinical Considerations: Family History}

Soliciting cancer family history information is crucial to diagnosing a hereditary cancer syndrome and the data should be recorded in every cancer-affected patient's medical chart. Given the variable genotypic and phenotypic features of hereditary CRC, inclusive of HNPCC, medical and pathology confirmation on cancer of all anatomic sites should be obtained whenever possible. It is necessary to record the age of each cancer onset, evaluate the pattern of multiple primary cancer occurrences, and note generation to generation transmission of cancers such as CRC and endometrium/ovarian carcinoma in HNPCC. Recognizing the possible reduced penetrance that may occur in cancer-prone lineages will be extremely important.

Ideally, genealogic and medical information should include three generations, i.e., the proband, parents, aunts and uncles, both sets of grandparents, and progeny (Figure 1). When evaluating the patient's parents, aunts and uncles, and both sets of grandparents, we are dealing with older individuals who, more than likely, will have passed through the cancer risk age and thereby will be genetically informative [6]. When collecting the cancer family history, as well as when interpreting the pedigree, an awareness of the cardinal features of hereditary cancer, as shown in Table 1, is extremely valuable.
Table 1. Cardinal features of hereditary cancer

Cardinal Features of Hereditary Cancer

* Earlier average age of cancer onset than in the general population; for example, the average age of CRC onset in HNPCC is $\approx 45$ years, while the average age of onset in sporadic CRC is $\approx 63$ years [6].

*A pattern of primary cancers segregating within the pedigree $[6,19]$.

* Possible survival differences [71, 79-81].

* Occasional pathology distinguishing features [82, 83].

* The sine qua non, the identification of a germline mutation segregating with syndrome-affected individuals in the family [45].

\section{History of HNPCC}

The history of what is known as HNPCC dates to an observation of Aldred Warthin, pathologist at the University of Michigan School of Medicine [7]. He became deeply moved when his seamstress, in 1895, told him that she would likely die of cancer of the colon, stomach, or her female organs, because of the enormous proclivity to these cancers in her family (unfortunately, just as she had told Warthin, she died at a young age of metastatic endometrial carcinoma). Warthin listened intently, developed her pedigree, and along with other similar cancer prone families published his work in 1913 [8]. Warthin updated the family in 1925 [9]. The seamstress's family has since been known as Family $G$.

\section{Patient's modified nuclear pedigree}

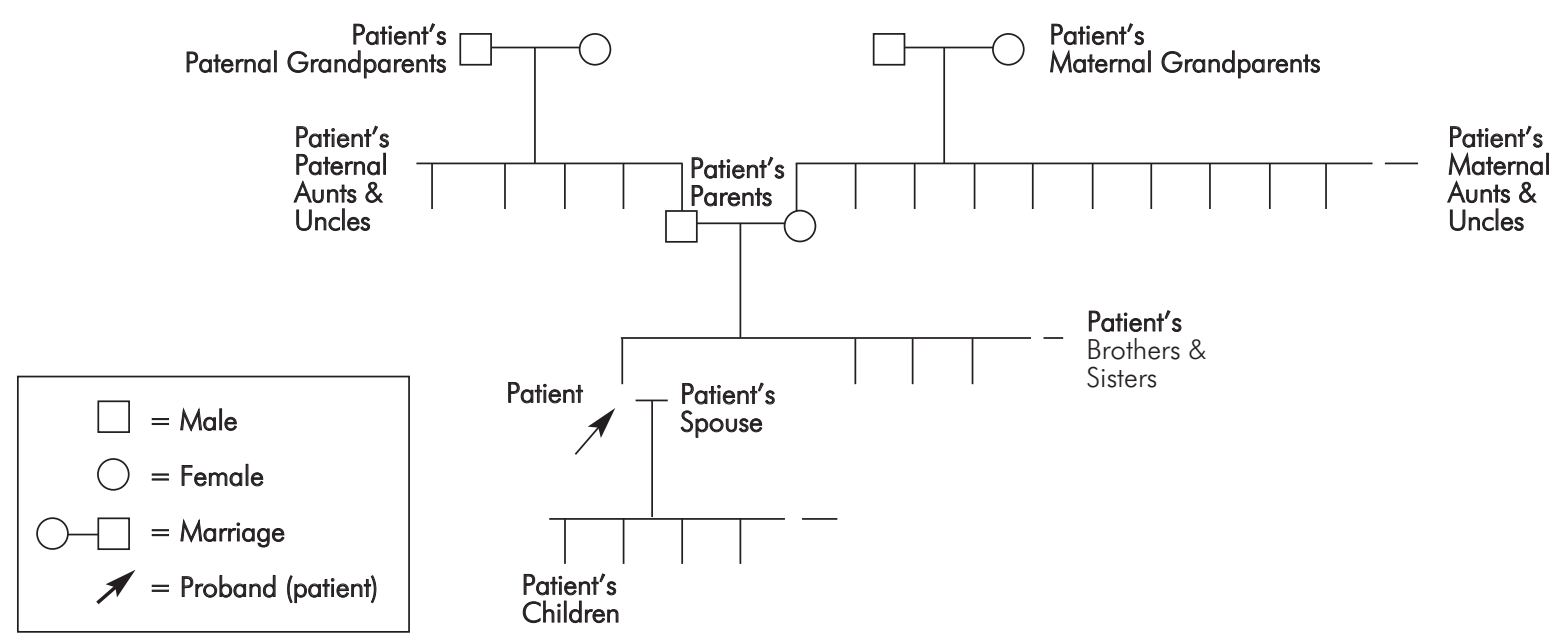

Fig. 1. Diagram reflecting the minimum information necessary to compile a cancer family history for hereditary cancer syndrome diagnosis. (Reprinted by permission from Lynch et al. Surv Dig Dis 1984; 2: 244-60) 
Lynch et al. [10] described the natural history and genetics of two large Midwestern kindreds (Families N and $M$ ) in 1966. The clinical genetic features in these families were similar to those of Family G [10]. Dr. A. James French, Warthin's successor as chairman of pathology at the University of Michigan, heard about Lynch's research on Families N and M, [10] and recalled that Warthin, his predecessor, had discovered a similar family (Family G) in 1895. Lynch was then invited by French to take custody of all the detailed documents and pathology specimens which the meticulous Warthin had investigated, catalogued, and published over a span of more than 30 years $[8,9]$. Family $G$ was then updated and published in 1971 [11]. This material is discussed in a more detailed review of the history of HNPCC [12]. Through the use of conversion technology, [13] an MSH2 mutation was identified in Family $G$ in the year 2000.

\section{What is HNPCC (Lynch Syndrome)?}

HNPCC is the most common autosomal dominantly inherited cancer syndrome that predisposes to colorectal cancer (CRC) $[5,6]$. Estimates of its frequency range from two to as much as seven percent of the total CRC burden [6, 14-16]. CRC occurs at an early age ( $\approx 44$ years), with right-sided predominance $(\approx 70 \%$ proximal to the splenic flexure), $[5,6,17]$ and a significant occurrence of synchronous and metachronous lesions $[6,18]$. There is an excess of extracolonic cancers, the most common of which is carcinoma of the endometrium, followed by cancers of the ovary, stomach (particularly in Asian countries such as Japan and Korea), small bowel, pancreas, hepatobiliary tract, brain, and transitional cell carcinoma of the upper uro-epithelial tract (Figure 2) $[19,20]$. Some families also have phenotypic manifestations such as sebaceous adenomas and/or sebaceous carcinomas consistent with the Muir-Torre syndrome (Figure 3) [6, 21-27]. Profuse colonic adenomas consonant with classical familial adenomatous polyposis (FAP) and its attenuated variant (AFAP) must be excluded in the medical evaluation of patients at high risk for $\operatorname{HNPCC}[5,6]$.

The Amsterdam criteria [28] and the more recent Amsterdam II criteria, [29] as well as the Bethesda [30] (Table 3) or European experts' [31, 32] guidelines are clinically useful in the diagnosis of HNPCC. However useful these criteria might be for assessing the diagnosis of HNPCC, there will be clinical situations wherein the family may be uninformative for their application, such as it often occurs in very small families. Additional
Table 2. Recommended colonic and extra-colonic surveillance in HNPCC

\begin{tabular}{ll}
\hline Site & Screening \\
\hline Colon & $\begin{array}{l}\text { Annual full colonoscopy initiated between } \\
\text { ages } 20 \text { and } 25\end{array}$ \\
\hline Endometrium & $\begin{array}{l}\text { Annual transvaginal ultrasound and } \\
\text { Pelvic examination beginning at age 30; } \\
\text { Endometrial aspiration for pathology assessment }\end{array}$ \\
\hline Ovary & $\begin{array}{l}\text { Transvaginal ovarian ultrasound } \\
\text { and CA-125 analysis (serious limitations } \\
\text { due to reduced sensitivity and specificity) }\end{array}$ \\
\hline $\begin{array}{l}\text { Stomach } \\
\text { Consider upper endoscopy in natives } \\
\text { an Korea or Japan and/or in families with }\end{array}$ \\
\hline $\begin{array}{l}\text { Upper } \\
\text { uro-epithelial } \\
\text { tract }\end{array}$ & $\begin{array}{l}\text { Urine samples for rbc and cytology } \\
\text { in concert with ultrasound }\end{array}$ \\
\hline $\begin{array}{l}\text { Other sites } \\
\text { Consider in families with an excess of cancer } \\
\text { of a particular extra-colonic site }\end{array}$ \\
\hline
\end{tabular}

factors which could obfuscate an HNPCC syndrome diagnosis in a patient/family and pose significant confounders for interpretation of the family history, include: a) false paternity; b) incomplete family history; c) reduced penetrance of the deleterious mutation in a key, otherwise informative individual such as the parent of an affected; d) loss or destruction of medical and pathology documents; e) poor cooperation; f) a situation where an otherwise informative individual has been adopted; or g) the death of one or more key family members early in life due to causes other than cancer. Therefore, many of the pertinent diagnostic features of HNPCC may not be present. However, in the face of these limitations, the cancer phenotype, particularly when severe, in a single family member, as evidenced in the family report discussed subsequently, may elucidate the HNPCC diagnosis.

\section{Colonic Adenomas and HNPCC}

A newly described feature of the Lynch syndrome phenotype pertains to the adenoma distribution in the colon. Specifically, Rijcken et al. [33] reasoned that in HNPCC the CRCs are believed to arise from adenomas in the proximal colon, since the CRCs occur predominantly in that anatomic area. They, therefore, investigated whether this proximal CRC predominance is due to a right-sided predominance of adenomas. In addition, they pursued whether there was a difference in rates of transformation of adenomas to cancer 


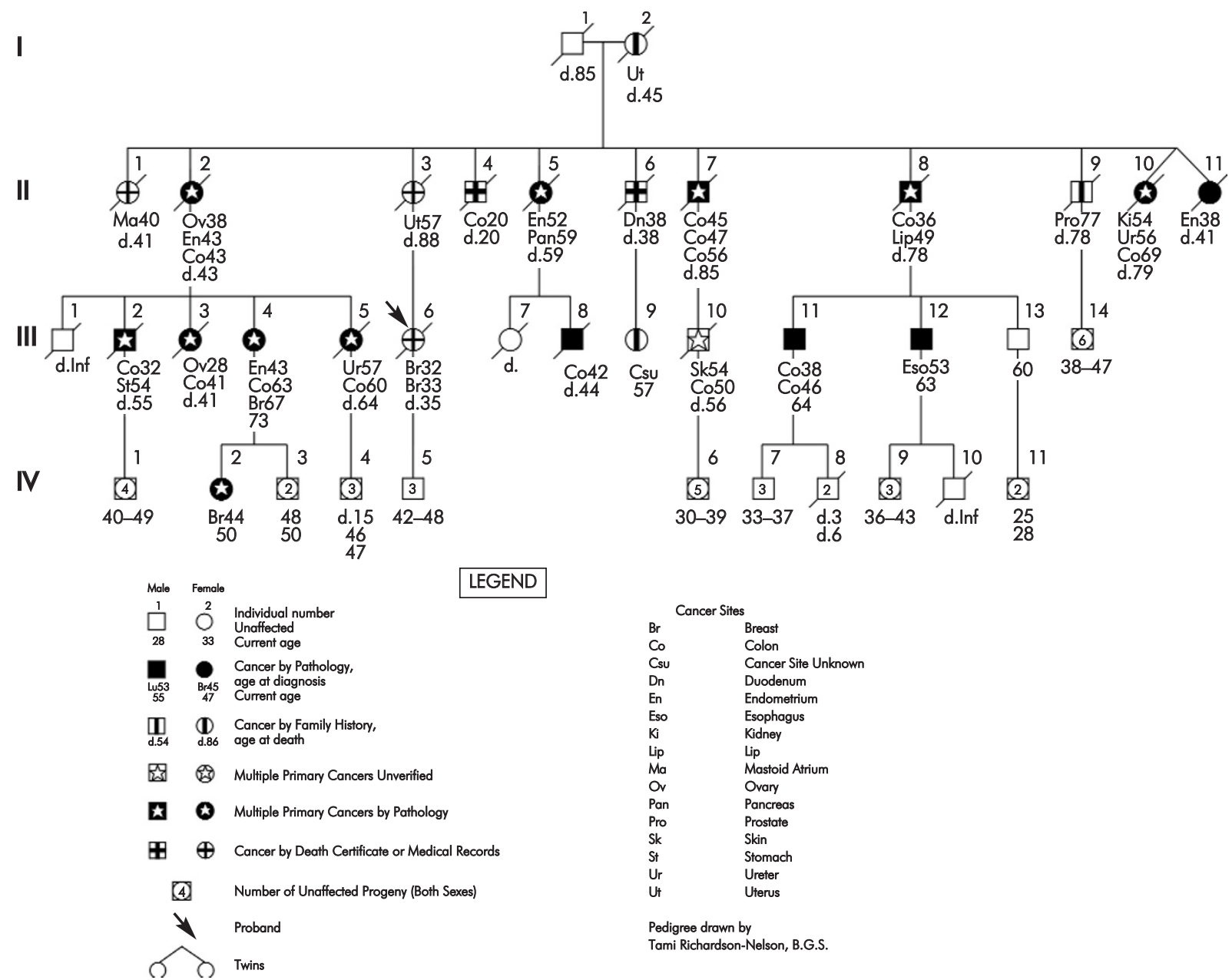

Fig. 2. Updated pedigree of an extended HNPCC family showing early age at cancer onset, occurrence of multiple primary syndrome cancers, at several anatomic sites. (Updated with permission from Lynch et al. Am J Gastroenterol 1988; 83: 741-7)

relevant to differences between distal and proximal colon location of the adenomas. They concluded that adenomas in HNPCC are located mainly in the proximal colon where they show progression to highgrade dysplasia which is more common in the proximal as opposed to distal HNPCC adenomas. These polyps also showed a faster malignant transformation rate from early adenoma to cancer in the proximal colon. They concluded that, "...MMR gene malfunction probably does not initiate adenoma development but is present at a very early stage of tumorigenesis and heralds the development of high grade dysplasia" [33].

Colonic adenomas, therefore, appear to differ in HNPCC when compared to their sporadic counterparts, wherein families with HNPCC show an earlier age at colonic adenoma onset coupled with a high degree of dysplasia. There appears to be a similar proximal localization of adenomas and carcinomas in
HNPCC, thereby suggesting an increased risk of cancer in all HNPCC adenomas [34, 35]. There also appears to be a faster progression of adenomas to CRC when compared to non-HNPCC families, who have a later onset and lower risk of cancer from proximal adenomas [33-35].

\section{Problem Clinical Examples of Existing HNPCC Diagnostic Criteria}

Cao et al. [36] describe a 62-year-old patient with duodenal adenocarcinoma who had previously undergone a subtotal colectomy for CRC. He had had only ten adenomatous colon polyps when he underwent a subtotal colectomy for cancer. Therefore, classic FAP was tentatively excluded. His brother had rectal cancer at age 69, his mother had CRC at age 75 , and one maternal cousin had colon cancer at age 42. The extreme rarity of duodenal adenocarcinoma 
Table 3. Bethesda Guidelines [30]

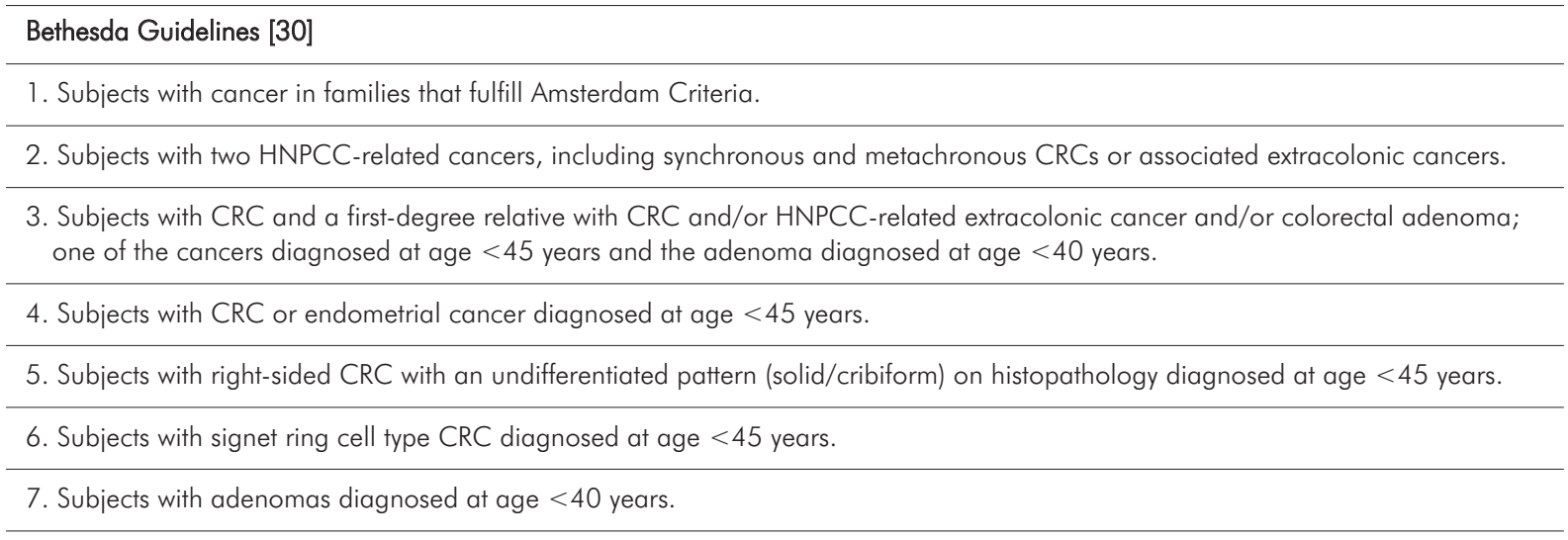

in the general population, coupled with the patient's family history of CRC, particularly late age of onset, caused attenuated familial adenomatous polyposis (AFAP) to be suspected [37].

During the course of this family study, it was only after the proband's 32-year-old son manifested rectal carcinoma that the family was found to fulfill the Amsterdam criteria for HNPCC. However, AFAP still could not be excluded. Germline testing of the proband was negative for the APC mutation, which suggested that AFAP was highly unlikely, but could not be completely excluded, since a small subset of FAP families will not harbor the APC mutation. However, microsatellite instability (MSI) was subsequently identified in the proband's adenomas and cancer tissues. Therefore, the fulfillment of the Amsterdam criteria, with exclusion of FAP and AFAP, in concert with MSI positivity, led to confidence in the diagnosis of HNPCC in the family. The phenotypic and genotypic differences among FAP, AFAP, and HNPCC must always be considered in the differential diagnosis of HNPCC.

\section{Genotype-Phenotype Heterogeneity}

HNPCC, not unlike other autosomal dominantly inherited disorders, is noteworthy for genotypic and phenotypic heterogeneity $[6,38,39]$. MSH2 mutations possibly predispose to the more severe phenotypic cancer phenomenon in HNPCC. For example, Vasen et al. [40] studied 138 families with HNPCC wherein mutations were identified in 79 of those families (34 with MLH1 , 40 with MSH2, 5 with MSH6). They found that the lifetime risk for developing cancer at any anatomic site was significantly higher for $\mathrm{MSH} 2$ mutation carriers as opposed to MLHT mutation carriers $(p<0.01)$. With respect to specific anatomic sites, findings disclosed that, "...The risk of developing colorectal or endometrial cancer was higher in MSH2 mutation carriers than in MLH1 mutation carriers, but the difference was not significant $(p=0.13$ and $p=0.057$, respectively). MSH2 mutation carriers were found to have a significantly higher risk of developing cancer of the urinary tract $(p<0.05)$. The risk of developing cancer of the ovaries, stomach and brain was also higher in the MSH2 mutation carriers than in the MLH1 mutation carriers, but the difference was not statistically significant."

\section{The Family Information Service (FIS)}

Genetic counseling must impart to the patient and his/her extended family important details about their genetic risk, based on the natural history of the hereditary cancer syndrome, their surveillance and management options, and the availability of genetic testing (Table 2) [41]. Education about these issues can be effectively provided to as many members of a hereditary cancer-prone family as elect to attend a group meeting [41]. We call such a meeting a family information service (FIS).

The FIS provides family members with a unique opportunity to empathize with each other about the impact of the "family disease" and, importantly, they can discuss their coping mechanisms with each other. They often appear to gain emotional strength through "group therapy" [42]. Often patients have stated that the FIS was the first time that a physician had told them what could "kill them", and, importantly, covered the advantages and disadvantages of germline mutation testing, and provided screening and management recommendations (Table 2). 

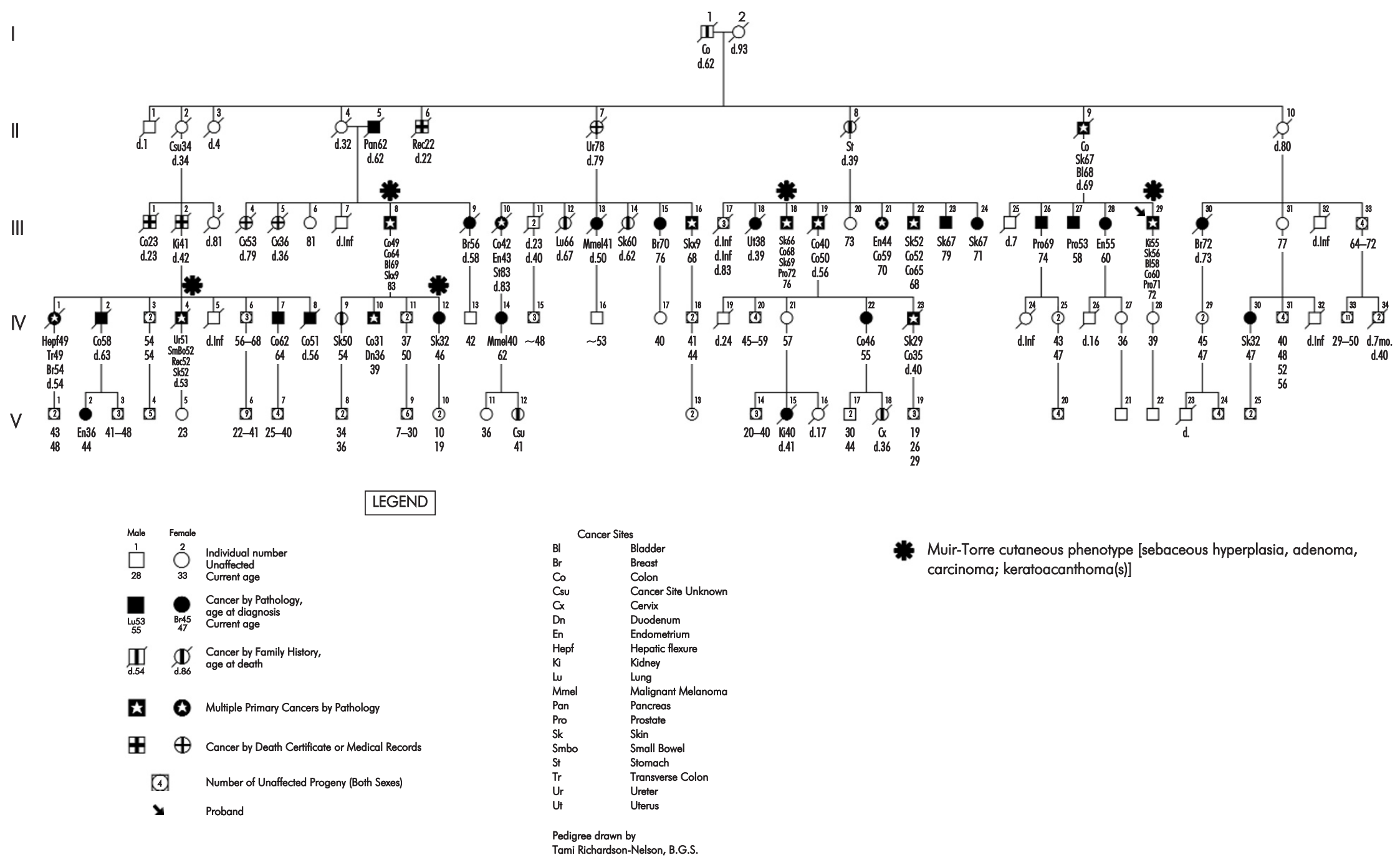

Muir-Torre cutaneous phenotype [sebaceous hyperplasia, adenoma

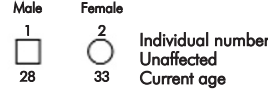

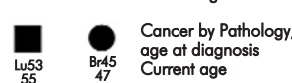

$\underset{\mathrm{d} .54}{\prod_{d .86}} \underset{\substack{\text { Cancer by Family History, } \\ \text { age at death }}}{ }$

\) Multiple Primary Cancers by Pathologr

由 $\oplus$ Cancer by Death Cerrificate or Medical Records

(4) Number of Unaffected Progeny (Both Sexes)

$y$ Proband

Pedigree drawn by

Fig. 3. Updated pedigree of a large HNPCC family reflecting the natural history features of the syndrome and, in addition, the Muir-Torre cutaneous phenotype. (Updated with permission from Lynch et al. Br J Dermatol 1985; 113: 295-301) 
Once the relevant germ line mutation has been identified through testing of a consenting syndrome cancer-affected family member, others are counseled and, when consenting, offered testing. When results of this testing become available, a second FIS is scheduled. The natural history of the disorder, the pros and cons of knowing one's DNA mutation status, and cancer screening and management information (inclusive of prophylactic surgical options), are discussed once again $[43,44]$. Mutation test results are then revealed on a one-to-one basis, once signed consent has been given.

\section{Genetic Counseling}

Genetic counseling must take place both prior to the collection of DNA and at the time of disclosure of the results. Ambiguous genetic test results (missense mutations) pose a diagnostic problem in that they cannot unequivocally be used to exclude cancer risk status. Specifically, one must consider a patient's position in the pedigree, whether or not a germline mutation has been identified in other first- and/or second-degree relatives of that patient and whether or not any extra-cancer phenotypic manifestations such as sebaceous adenomas and/or sebaceous carcinomas consistent with the Muir-Torre syndrome variant of HNPCC, might be identified. In short, one cannot entirely exclude hereditary cancer susceptibility based upon an ambiguous genetic test result [45].

When the diagnosis of hereditary CRC is confirmed, one then ideally considers the proband's high-risk relatives and implements genetic counseling and DNA testing in these consenting individuals, as well as surveillance measures which need to be implemented in accord with the disorder's natural history in the interest of reduction of cancer's morbidity and mortality (Table 2). It is in this realm that consultation with a cancer genetics center may complete this cancer prevention cycle [6]. Although physicians' knowledge about cancer genetics is improving, several studies have shown the need for a better understanding of this area [46-48].

\section{Informed Consent and Molecular Genetic Testing}

Prior to the collection of peripheral blood lymphocytes for DNA, which will be used for germline mutation testing, the patient must provide informed consent. This is a process which involves the patient as a knowledgeable adult participant, meaning that he or she has been thoroughly educated about the disorder and the implications of receipt of information regarding the cancer phenotype and its penetrance due to a cancer-causing germline mutation. The significance of a negative finding when a mutation has not been identified in the family must also be fully explained. A true negative mutation result must be based upon the identification of the mutation in the family, including its segregation in syndrome cancer affecteds (a true positive mutation). The short- as well as long-term psychological and cancer (phenotype) impact of such a mutation finding must then be discussed $[6,41,49]$.

Respect must be given to the patient's autonomy as well as self-determination relevant to the medical decision-making process. The nature and purpose of the DNA studies, risks and benefits of knowing the results, as well as penalties such as the potential for insurance or employment discrimination, coupled with the fact that the outcome of testing will in no way guarantee success through management, must be understood by the patient (For a review, see Rex et al. [50]).

\section{DNA Testing Strategies: MSI, Immunohistochemistry, and Mismatch Repair Mutation Testing}

The ultimate objective of DNA testing is to discern who is at inordinately high risk for cancer by virtue of manifesting the specific cancer-causing germline mutation, thereby indicating the necessity of preventive procedures or early treatment.

\section{Molecular Genetics of Lynch Syndrome}

Mutations in six different MMR genes have been identified in HNPCC patients: MLHT, located on chromosome $3 p 21$; MSH2 on 2p16, MSH6 on 2p15; PMS2 on 7p22; MLH3 on 14q24.3; and possibly PMS1 [51], located on 7p22 [51-57]. However, only $40-60 \%$ of HNPCC patients harbor identifiable germline mutations, most common of which are $\mathrm{MSH} 2$ and $\mathrm{MLH} 1$ mutations [58]. Approximately $90 \%$ of the identified HNPCC mutations involve MLH1 or MSH2, while mutations in the MSH6 gene account for approximately $10 \%$. MSH6 mutations appear to predispose to an excess of endometrial cancer and a deficit of CRC [39]. These findings therefore suggest that other genes, including modifier genes, may be of etiologic importance in HNPCC. The occurrence of mutation types that are difficult to detect, environmental factors, and/or chance could also 
explain the etiology of those $40-60 \%$ of HNPCC families in which no known cancer-causative germline mutations have to date been identified $[6,59]$. The mutation database maintained by the ICG-HNPCC is an important source of first reference (www.nfdht.nl).

Molecular genetic testing of a genetically informative affected family member is the sine qua non for establishing an unequivocal HNPCC diagnosis. This can be partially facilitated by the finding of positivity of microsatellite instability or loss of MMR gene protein expression in a malignant colon tumor in the HNPCC family setting [58]. Testing for a mismatch repair germline mutation, when present, will be confirmatory of HNPCC. In turn, family members who are negative for the mutated MMR gene will not have to undergo the rigorous screening which will be recommended for those who are positive, and will revert to general population screening recommendations. As mentioned, a true negative DNA diagnosis can be established with certainty only when the subject germline mutation has been identified in an affected informative relative and, ideally, when it has segregated in the family among additional HNPCC affecteds.

Exon by exon sequencing is the most sensitive technique for the detection of germline mutations in HNPCC using genomic DNA as the template for analysis. However, cost and sensitivity limitations can partially be overcome by RNA-based analysis [60]. Jakubowska et al. note that, "...primers specific for RT [reverse transcription] of $\mathrm{MLH} 1$ and MSH2 are crucial for increasing the sensitivity of cDNA analysis. DNA sequencing using RNA as a basis for template construction may be a valuable and economical alternative to genomic DNA sequencing" [60].

In many cases, immunohistochemical analysis of the MMR gene protein in the tumor can provide clues as to which MMR gene is involved if staining for one of the proteins is weak or absent $[61,62]$. Wahlberg et al. [63] studied 48 HNPCC families where a tumor sample was available for the evaluation of the presence of germline mutations in $\mathrm{MSH} 2$ and $M L \mathrm{H} 1$, for MSI, and, whenever possible, expression of $\mathrm{MSH} 2$ and MLH1 in tumors by immunohistochemistry (IHC). Genomic DNA sequencing revealed 14 of the 48 families to harbor a germline mutation in either MSH2 or MLH1. Loss of expression of MSH2 was found in four additional families, while one additional family showed loss of expression of MLH7 but did not harbor a germline mutation in $\mathrm{MSH} 2$ or MLH7 that could be detected by DNA sequencing. MSI-H (MSI-High) showed $100 \%$ sensitivity for identifying samples having MSH2 or MLH1 mutations or loss of protein expression.
However, loss of MSH2 and MLH1 expression failed to identify all samples showing germline mutations in $M S H 2$ or $M L H 1$, since in five cases a mutant protein product was expressed that would be detected by $\mathrm{IHC}$. The authors concluded that, "...a combination of the Bethesda criteria for HNPCC and MSI-H phenotype defined the smallest number of cases having all of the germ-line $\mathrm{MSH} 2$ and $\mathrm{MLH} 1$ mutations that could be detected by DNA sequencing" [63].

Debniak et al. [64] evaluated the cost-effectiveness of pedigree/clinical data, IHC, and MSI analysis. Cost reduction of $\mathrm{MLH1}$ and $\mathrm{MSH} 2$ germline mutation testing in individuals at high risk for CRC is always an important consideration. Herein, they evaluated 168 patients with CRC which included 43 consecutive sporadic late-onset and 25 consecutive likely HNPCC cases examined by IHC and MSI. In the HNPCC suspect cases, 6 of 25 (24\%) patients with constitutional mutations were identified, while no germline mutations were found in the sporadic late-onset subjects. Of keen interest was the finding that, "...The lowest costs (880 Euro/mutation detected) were achieved by performing pedigree/clinical data (for exclusion of late-onset sporadic CRC) in conjunction with $\mathrm{IHC}$ only. In this model, $1 / 6$ (17\%) mutations were missed. Additional preselection by $\mathrm{IHC}$ and $\mathrm{MI}$ [MSI] analyses before sequencing was required to detect all mutations. In this approach, which seems to be the most effective in the search for hMLHI and hMSH2 gene mutation, the cost was 1767 Euro/mutation detected."

\section{Assessing the Pathogenicity of Mutations}

All coding genomic changes are potentially deleterious, the most straightforward ones being those that are of nonsense type (that is, create a stop codon or lead to a frameshift) or those that cause abnormal splicing. In contrast, those mutations that lead to only an amino acid substitution (missense mutations) cannot be considered a priori pathogenic. Of all HNPCC mutations so far seen in $\mathrm{MLHI}$ and $\mathrm{MSH} 2,29 \%$ and $16 \%$ respectively are of missense type. In reality, many missense mutations make interpretation an ordeal. Furthermore, most studies to date have not included analysis of MSH6 that undoubtedly causes HNPCC or an HNPCC-like predisposition [55].

\section{Cancer Surveillance}

Cancer control is mandatory for sporadic as well as hereditary forms of CRC. Importantly, one must stratify CRC risk status and then meld cancer prevention strategies to the natural history of the patient's lifetime cancer risk [65]. 
In HNPCC, annual full colonoscopy initiated between ages 20 and 25 is recommended for those with strong clinical evidence and/or MLH1, MSH2, or MSH6 germline mutations. Less frequent (every 3 years) colonoscopy has been suggested in a consensus statement, [66] but we believe this would lead to missed $C R C s$, given the phenomenon of accelerated carcinogenesis $[6,34,67,68]$. Table 2 shows our surveillance recommendations for extra-colonic cancers in HNPCC. For example, endometrial screening includes annual transvaginal ultrasound and pelvic examination beginning at age 30. Transvaginal ovarian ultrasound and CA- 125 analysis may be helpful for ovarian cancer surveillance in some patients; however, their reduced sensitivity and specificity pose serious limitations to these procedures. Screening for other organ sites such as upper uro-epithelial tract and stomach cancer (particularly in natives of Korea [69] or Japan and/or when an excess of these extracolonic cancers occur within a particular family) must also be considered. Surgical prophylaxis (prophylactic subtotal colectomy, and prophylactic total abdominal hysterectomy and bilateral salpingo-oophorectomy is presented as an option to selected patients $[6,43]$.

The efficacy of CRC surveillance in HNPCC was evaluated in a controlled clinical trial extending over 15 years [70]. The incidence of CRC was compared in two cohorts of at-risk members of 22 HNPCC families. CRC developed in eight screened subjects (6\%), compared with 19 controls $(16 \% ; p=0.014)$. The CRC rate was reduced by $62 \%$. All CRCs in the screened group were local, causing no deaths, compared with nine deaths caused by CRC in the controls. It was concluded that CRC screening at threeyear intervals more than cuts in half the risk of CRC, prevents CRC deaths, and decreases overall mortality by about $65 \%$ in HNPCC families. The relatively high incidence of CRC even in the screened subjects (albeit without deaths) argues for shorter screening intervals, e.g., one year.

\section{Survival Benefit in HNPCC}

In spite of its ominous pathology features and the proclivity to multiple primary CRCs, when compared for age and stage with CRC in the general population, the estimated death rate from CRC in HNPCC has been reported to be, at most, only two-thirds of that in sporadic CRC cases [71]. Interestingly, improved survival was also one of the original defining features of the MTS phenotype of HNPCC $[6,21-25,27]$. The reason(s) for this improved survival remain elusive. It is possible that immunologic factors may be responsible, as evidenced by a peritumoral lymphocytic infiltration, the presence of a Crohn's-like reaction, and a marked excess of tumor infiltrating lymphocytes (TILs) [72].

\section{Conclusion}

The diagnosis of HNPCC in certain clinical settings may prove extremely difficult, given the many obfuscating factors discussed in this review. The lack of premonitory clinical signs, save the cutaneous features of the Muir-Torre phenotype, [21-25, 27] to aid in the diagnosis, is a particular obstacle to its diagnosis. This is truly a pity, since the cancer preventive opportunities, once a diagnosis of a high-risk individual is established, truly abound.

The bulk of the human genome has been mapped [73]. This prodigious effort holds promise that more cancer susceptibility genes will be found. Nevertheless, as we continue to travel with anticipation and excitement into the brave new world of molecular biology, we will need clinicians to utilize cancer genetics as an important tool for cancer prevention. We will, unfortunately, not be able to fulfill this objective in the absence of well-thought-out descriptive family studies. It is this very area that remains a blight to cancer genetic progress, since it is still rare to examine a medical chart and identify useful information about that patient's family history of cancer $[74,75]$. However, on the positive side, a clinician who is armed with knowledge about the genotypic and phenotypic features of hereditary cancer syndromes, particularly when coupled with a willingness to inquire about the patient's family history, will be in a most coveted position to establish a diagnosis and then effectively screen for those targeted organs that constitute a hereditary cancer syndrome.

Identifying HNPCC potentially saves lives through early cancer detection [70, 76]. This effect was quantified in a study by Ramsey at al. [77] in a costeffectiveness analysis comparing standard care to a process including application of the Bethesda guidelines, [30] followed by testing of the tumor for MSI, then germline testing. In the case of mutation carriers, life-long colorectal cancer surveillance was indicated. Results showed cost-effectiveness of surveillance up to $\$ 7,556$ per life-year gained. Benefits were greatest when immediate relatives (siblings and children) of the index case were considered [77].

Reyes et al. [78] discuss selection strategies for genetic testing of patients with HNPCC. They point out that molecular testing for HNPCC is becoming standard care and that it is cost-effective when compared to the absence of such genetic testing. Using 
a decision analytic model for evaluating the effectiveness and incremental cost-effectiveness of four presently-used testing strategies for detection of HNPCC gene carriers, they initiated their model in the population of CRC patients, measured the costs, the number of gene carriers tested, in concert with incremental cost per gene carrier detected. Findings disclosed that germline testing on only those CRC probands who meet the Amsterdam criteria detected the fewest number of gene carriers and had the lowest cost. This was in contrast to MSI testing of all CRC patients and families, which amounted to the highest cost but detected the most gene carriers. Furthermore, "... When cost effectiveness is considered, the mixed strategy $\mathrm{MSH} 2$ and $\mathrm{MLH} 1$ testing on those who meet the Amsterdam criteria and germline testing for the remainder who meet less stringent modified criteria and are MSI-High) seems superior. The mixed strategy detects 59.6 mutation carriers per 1,000 CRC cases and costs much less than the test all strategy, which has an incremental cost-effectiveness of $\$ 51,151$. The mixed strategy ... when compared to the Amsterdam strategy, has a cost-effectiveness of only $\$ 6,441$ per gene carrier detected." These authors concluded that it is not very effective to restrict testing to only those individuals who meet the Amsterdam criteria, since many gene carriers will be missed. On the other hand, testing all CRC patients for tumor MSI-H, while effective, may be prohibitively expensive and therein a mixed strategy is the more effective approach.

This review of HNPCC has merely grazed the surface of the proverbial iceberg when considering its immense complexity. Issues to be solved for the elucidation and control of HNPCC include the following:

1. What is its "complete" tumor complement?

2. What are its chemotherapy and chemoprevention implications?

3. Can we improve its surveillance/management strategies?

4. Can we achieve molecular-based cancer prevention for it?

5. What are its genotypic/phenotypic heterogeneity implications?

6. What are its differential diagnostic implications?

\section{References}

1. International Agency for Research on Cancer. Globocan 2000 International Agency for Research on Cancer. http://wwwdep.iarc.fr/globocan/globocan.html, 2002.

2. Jemal A, Thomas A, Murray T, Thun M. Cancer statistics, 2002. CA Cancer J Clin 2002; 52: 23-47.
3. Laken SJ, Petersen GM, Gruber SB, Oddoux C, Ostrer H, Giardiello FM, Hamilton SR, Hampel H, Markowitz A, Klimstra D, Jhanwar S, Winawer S, Offit K, Luce MC, Kinzler KW, Vogelstein B. Familial colorectal cancer in Ashkenazim due to a hypermutable tract in APC. Nat Genet 1997; 17: 79-83.

4. Herrera L, editors. Familial Adenomatous Polyposis. New York: Alan R. Liss, Inc. 1990

5. Lynch HT, Smyrk TC. Classification of familial adenomatous polyposis: a diagnostic nightmare. Am J Hum Genet 1998; 62: 1288-9.

6. Lynch HT, de la Chapelle A. Genetic susceptibility to nonpolyposis colorectal cancer. J Med Genet 1999; 36: 801-18.

7. Thorson A, Knezetic JA, Lynch HT. A century of progress in hereditary nonpolyposis colorectal cancer (Lynch syndrome). Dis Colon Rectum 1999; 42: 1-9.

8. Warthin AS. Heredity with reference to carcinoma as shown by the study of the cases examined in the pathological laboratory of the University of Michigan, 1895-1913. Arch Intern Med 1913; 12: 546-55.

9. Warthin AS. The further study of a cancer family. J Cancer Res 1925; 9: 279-86.

10. Lynch HT, Shaw MW, Magnuson cW, Larsen AL, Krush AJ. Hereditary factors in cancer: study of two large Midwestern kindreds. Arch Intern Med 1966; 117: 206-12.

11. Lynch HT, Krush AJ. Cancer family "G" revisited: 1895-1970. Cancer 1971; 27: 1505-11.

12. Lynch HT, Smyrk T, Lynch JF. Molecular genetics and clinicalpathology features of hereditary nonpolyposis colorectal carcinoma (Lynch syndrome): historical journey from pedigree anecdote to molecular genetic confirmation. Oncology 1998; 55: 103-8.

13. Yan H, Papadopoulos N, Marra G, Perrera C, Jiricny J, Boland CR, Lynch HT, Chadwick RB, de la Chapelle A, Berg K, Eshleman JR, Yuan W, Markowitz S, Laken SJ, Lengaver C, Kinzler KW, Vogelstein B. Conversion of diploidy to haploidy: individuals susceptible to multigene disorders may now be spotted more easily. Nature 2000; 403: 723-4.

14. Lynch J. The genetics and natural history of hereditary colon cancer. Seminars in Oncology Nursing 1997; 13: $91-8$.

15. Aaltonen LA, Salovaara R, Kristo P, Canzian F, Hemminki A, Peltomaki P, Chadwick RB, Kaariainen H, Eskelinen M, Jarvinen $\mathrm{H}$, Mecklin JP, de la Chapelle A. Incidence of hereditary nonpolyposis colorectal cancer and the feasibility of molecular screening for the disease. N Engl J Med 1998; 338: 1481-7.

16. Salovaara R, Loukola A, Kristo P, Kaariainen H, Ahtola H, Eskelinen M, Harkonen N, Julkunen R, Kangas E, Ojala S, Tulikoura J, Valkamo E, Jarvinen H, Mecklin JP, Aaltonen LA, de la Chapelle A. Population-based molecular detection of hereditary nonpolyposis colorectal cancer. J Clin Oncol 2000; 18: 2193-200.

17. Lynch PM, Lynch HT, Harris RE. Hereditary proximal colonic cancer. Dis Colon Rectum 1977; 20: 661-8.

18. Lynch HT, Krush AJ, Larsen AL. Heredity and multiple primary malignant neoplasms: six cancer families. Am J Med Sci 1967; 254: 322-9.

19. Watson P, Lynch HT. The tumor spectrum in HNPCC. Anticancer Res 1994; 14: 1635-40.

20. Aarnio M, Sankila R, Pukkala E, Salovaara R, Aaltonen LA, de la Chapelle A, Peltomaki P, Mecklin JP, Jarvinen HJ. Cancer risk in mutation carriers of DNA-mismatch-repair genes. Int J Cancer 1999; 81: 214-18.

21. Fusaro RM, Lynch HT, Pester J, Lynch PM. Torre's syndrome as phenotypic expression of cancer family syndrome. Arch Dermatol 1980; 116: 986-7.

22. Lynch HT, Lynch PM, Pester JA, Fusaro RM. Sebaceous neoplasia and visceral cancer (Torre's syndrome) and its relationship to the cancer family syndrome. In: Lynch HT, Fusaro RM, editors. Cancer-associated Genodermatoses. New York: Van Nostrand Reinhold, 1982: 366-93. 
23. Lynch HT, Fusaro RM, Roberts L, Voorhees GJ, Lynch JF. Muir-Torre syndrome in several members of a family with a variant of the cancer family syndrome. Br J Dermatol 1985; 1 13: 295-301.

24. Lynch HT, Fusaro RM. Muir-Torre syndrome: heterogeneity, natural history, diagnosis, and management. Prob Gen Surg 1993; 10: 1-14

25. Lynch HT, Leibowitz R, Smyrk T, Fusaro RM, Lynch JF, Smith A Franklin B, Stella A, Liu B. Colorectal cancer and the Muir-Torre syndrome in a Gypsy family: a review. Am J Gastroenterol 1999. 94: $575-80$

26. Peltomaki P, Aaltonen LA, Sistonen P, Pylkkanen L, Mecklin JP, Jarvinen $H$, Green JS, Jass JR, Weber JL, Leach FS, Petersen GM, Hamilton SR, de la Chapelle A, Vogelstein B. Genetic mapping of a locus predisposing to human colorectal cancer. Science 1993; 260: 810-12.

27. Fusaro RM, Lemon SJ, Lynch HT. The Muir-Torre syndrome: a variant of hereditary nonpolyposis colorectal cancer syndrome. J Tumor Marker Oncol 1996; 11: 19-31.

28. Vasen HFA, Mecklin J-P, Meera Khan P, Lynch HT. The International Collaborative Group on Hereditary Nonpolyposis Colorectal Cancer (ICG-HNPCC). Dis Colon Rectum 1991; 34: 424-5.

29. Vasen HFA, Watson P, Mecklin J-P, Lynch HT, ICG-HNPCC. New clinical criteria for hereditary nonpolyposis colorectal cancer (HNPCC, Lynch syndrome) proposed by the International Collaborative Group on HNPCC. Gastroenterology 1999; 116: 1453-6.

30. Rodriguez-Bigas MA, Boland CR, Hamilton SR, Henson DE, Jass JR, Khan PM, Lynch H, Perucho M, Smyrk T, Sobin L, Srivastava S. A National Cancer Institute workshop on hereditary nonpolyposis colorectal cancer syndrome: meeting highlights and Bethesda Guidelines. J Natl Cancer Inst 1997; 89: 1758-62.

31. Standards for a model registry - recommendations for diagnosis, surveillance and treatment of selected CFS, EC Grant number QLRICT-1999-00063. http://www.republika.pl/genetyka/standards.htm, 2002.

32. Kladny J, Möslein G, Myrhøj T, Kurzawski G, Jakubowska A, Debniak T, Petriczko W, Kozlowski M, Al-Amawi T, Brzosko M, Flicinski J, Jawien A, Banaszkiewicz A, Richter P, Lubinski J. Nuclear pedigree criteria of suspected HNPCC. Her Can Clin Pract 2003; 1 (1): 34-8.

33. Rijcken FEM, Hollema H, Kleibeuker JH. Proximal adenomas in hereditary non-polyposis colorectal cancer are prone to rapid malignant transformation. Gut 2002; 50: 382-6.

34. Jass JR, Stewart SM. Evolution of hereditary non-polyposis colorectal cancer. Gut 1992; 33: 783-6.

35. Lindgren $G$, Liliegren $A$, Jaramillo $E$, Rubio $C$, Lindblom A. Adenoma prevalence and cancer risk in familial non-polyposis colorectal cancer. Gut 2002; 50: 228-34

36. Cao Y, Pieretti M, Marshall J, Khattar NH, Chen B, Kam-Morgan $\mathrm{L}$, Lynch $\mathrm{H}$. Challenge in the differentiation between attenuated familial adenomatous polyposis and hereditary nonpolyposis colorectal cancer: case report with review of the literature. Am J Gastroenterol 2002; 97: 1823-7.

37. Lynch HT, Smyrk T, McGinn T, Lanspa S, Cavalieri J, Lynch J, Slominski-Castor S, Cayouette MC, Priluck I, Luce MC. Attenuated familial adenomatous polyposis (AFAP): a phenotypically and genotypically distinctive variant of FAP. Cancer 1995; 76: 2427-33.

38. Nicolaides NC, Littman SJ, Modrich P, Kinzler KW, Vogelstein B. A naturally occurring hPMS2 mutation can confer a dominant negative mutator phenotype. Mol Cell Biol 1998; 18: 1635-41.

39. Wijnen J, de Leeuw W, Vasen $\mathrm{H}$, van der Klift $\mathrm{H}$, Moller $\mathrm{P}$, Stormorken A, Meijers-Heijboer $H$, Lindhout D, Menko F, Vossen S, Moslein G, Tops C, Brocker-Vriends A, Wu Y, Hofstra R, Siimons R, Cornelisse C, Morreau H, Fodde R. Familial endometrial cancer in female carriers of MSH6 germline mutations. Nat Genet 1999; 23: 142-4

40. Vasen HF, Stormorken A, Menko FH, Nagengast FM, Kleibeuker JH, Griffioen G, Taal BG, Moller P, Wijnen JT. MSH2 mutation carriers are at higher risk of cancer than MLHI mutation carriers: a study of hereditary nonpolyposis colorectal cancer families. J Clin Oncol 2001; 19: 4074-80.

41. Lynch HT. Family Information Service and hereditary cancer. Cancer 2001; 91: 625-8.

42. Lynch HT. Dynamic Genetics Counseling for Clinicians. Springfield, Illinois: CC Thomas, 1969.

43. Lynch HT. Is there a role for prophylactic subtotal colectomy among hereditary nonpolyposis colorectal cancer germline mutation carriers? Dis Colon Rectum 1996; 39: 109-10.

44. Church JM. Prophylactic colectomy in patients with hereditary nonpolyposis colorectal cancer. Ann Med 1996; 28: 479-82.

45. Vogelstein B, Kinzler KW, editors. The Genetic Basis of Human Cancer. New York: McGraw-Hill, 1998.

46. Polednak AP. Do physicians discuss genetic testing with family-historypositive breast cancer patients? Conn Med 1998; 62: 3-7.

47. Cho MK, Sankar P, Wolpe PR, Godmilow L. Commercialization of BRCA1/2 testing: practitioner awareness and use of a new genetic test. Am J Med Genet 1999; 83: 157-63.

48. Giardiello FM, Brensinger JD, Petersen GM, Luce MC, Hylind LM, Bacon JA, Booker SV, Parker RD, Hamilton SR. The use and interpretation of commercial APC gene testing for familial adenomatous polyposis. N Engl J Med 1997; 336: 823-7.

49. Aktan-Collan K, Mecklin JP, Jarvinen H, Nystrom-Lahti M, Peltomaki P, Soderling I, Uutela A, de la Chapelle A, Kaariainen $\mathrm{H}$. Predictive genetic testing for hereditary non-polyposis colorectal cancer: Uptake and long-term satisfaction. Int J Cancer (Pred Oncol) 2000; 89: 44-50.

50. Rex DK, Bond JH, Feld AD. Medical-legal risks of incident cancers after clearing colonoscopy. Am J Gastroenterol 2001; 96: 952-7.

51. Nicolaides NC, Papadopoulos N, Liu B, Wei YF, Carter KC, Ruben SM, Rosen CA, Haseltine WA, Fleischmann RD, Fraser CM, Adams MD, Venter JC, Dunlop MG, Hamilton SR, Petersen GM, de la Chapelle A, Vogelstein B, Kinzler KW. Mutations of two PMS homologues in hereditary nonpolyposis colon cancer. Nature 1994; 371: 75-80.

52. Bronner CE, Baker SM, Morrison PT, Warren G, Smith LG, Lescoe MK, Kane M, Earabino C, Lipford J, Lindblom A, Tannergard P, Bollag RJ, Godwin AR, Ward DC, Nordenskild M, Fishel R, Kolodner R, Liskay RM. Mutation in the DNA mismatch repair gene homologue hMLH1 is associated with hereditary nonpolyposis colon cancer. Nature 1994; 368: 258-61.

53. Fishel R, Lescoe MK, Rao MR, Copeland NG, Jenkins NA, Garber J, Kane M, Kolodner R. The human mutator gene homolog $\mathrm{MSH} 2$ and its association with hereditary nonpolyposis colon cancer. Cell 1993; 75: 1027-38.

54. Akiyama Y, Sato H, Yamada T, Nagasaki H, Tsuchiya A, Abe R, Yuasa Y. Germ-line mutation of the hMSH6/GTBP gene in an atypical hereditary nonpolyposis colorectal cancer kindred. Cancer Res 1997; 57: 3920-3

55. Miyaki M, Konishi M, Tanaka K, Kikuchi-Yanoshita R, Muraoka M, Yasuno M, Igari T, Koike M, Chiba M, Mori T. Germline mutation of MSH6 as the cause of hereditary nonpolyposis colorectal cancer. Nat Genet 1997; 17: 271-2.

56. Wu Y, Berends MJ, Sijmons RH, Mensink RG, Verlind E, Kooi KA, van der Sluis $T$, Kempinga $C$, van dDer Zee AG, Hollema $H$, Buys $\mathrm{CH}$, Kleibeuker JH, Hofstra RM. A role for MLH3 in hereditary nonpolyposis colorectal cancer. Nat Genet 2001; 29: 137-8.

57. Lipkin $S M$, Wang $V$, Jacoby $R$, Baneriee-Basu $S$, Baxevanis $A D$, Lynch HT, Elliott RM, Collins FS. MLH3: a DNA mismatch repair gene associated with mammalian microsatellite instability. Nat Genet 2000; 24: 27-34. 
58. de la Chapelle A. Microsatellite instability phenotype of tumors: genotyping or immunohistochemistry? The jury is still out. J Clin Oncol 2002; 20: 897-9.

59. Peltomäki P, Vasen HFA, International Collaborative Group on Hereditary Nonpolyposis Colorectal Cancer. Mutations predisposing to hereditary nonpolyposis colorectal cancer: database and results of a collaborative study. Gastroenterology 1997; 113: 1146-58.

60. Jakubowska A, Gorski B, Kurzawski G, Debniak T, Hadaczek P, Cybulski C, Kladny J, Oszurek O, Scott RJ, Lubinski J. Optimization of experimental conditions for RNA-based sequencing of MLH 1 and MSH2 genes. Hum Mutat 2001; 17: 52-60.

61. Thibodeau SN, French AJ, Cunningham JM, Tester D, Burgart LJ, Roche PC, McDonnell SK, Schaid DJ, Vockley CW, Michels W, Farr GH Jr, O'Connell MJ. Microsatellite instability in colorectal cancer: different mutator phenotypes and the principal involvement of hMLH1. Cancer Res 1998; 58: 1713-18.

62. Lindor NM, Burgart LJ, Leontovich $O$, Goldberg RM, Cunningham JM, Sargent DJ, Walsh-Vockley C, Petersen GM, Walsh MD, Leggett BA, Young JP, Barker MA, Jass JR, Hopper J, Gallinger S, Bapat B, Redston M, Thibodeau SN. Immunohistochemistry versus microsatellite instability testing in phenotyping colorectal tumors. J Clin Oncol 2002; 20: 1043-8.

63. Wahlberg SS, Schmeits J, Thomas G, Loda M, Garber J, Synga S, Kolodner RD, Fox E. Evaluation of microsatellite instability and immunohistochemistry for the prediction of germ-line MSH2 and $\mathrm{MLH} 1$ mutations in hereditary nonpolyposis colon cancer families. Cancer Res 2002; 62: 3485-92.

64. Debniak T, Kurzawski G, Gorski B, Kladny J, Domagala W, Lubinski J. Value of pedigree/clinical data, immunohistochemistry and microsatellite instability analyses in reducing the cost of determining $\mathrm{hMLH} 1$ and $\mathrm{hMSH} 2$ gene mutations in patients with colorectal cancer. Eur J Cancer 2000; 36: 49-54.

65. Levin B, Smith RA, Feldman GE, Colditz GA, Fletcher RH, Nadel M, Rothenberger DA, Schroy PS 3rd, Vernon SW, Wender R; National Colorectal Cancer Roundtable. Promoting early detection tests for colorectal carcinoma and adenomatous polyps. A framework for action: the strategic plan of the National Colorectal Cancer Roundtable. Cancer 2002; 95: 1618-28.

66. Burke W, Daly M, Garber J, Botkin J, Kahn MJ, Lynch P, McTiernan A, Offit K, Perlman J, Petersen G, Thomson E, Varricchio C. Recommendations for follow-up care of individuals with an inherited predisposition to cancer: I. Hereditary nonpolyposis colon cancer. JAMA 1997; 277: 915-19.

67. Jass JR, Do KA, Simms LA, lino H, Wynter C, Pillay SP, Searle J, Radford-Smith G, Young J, Leggett B. Morphology of sporadic colorectal cancer with DNA replication errors. Gut 1998; 42: 673-9

68. Jass JR. Colorectal adenoma progression and genetic change: is there a link? Ann Med 1995; 27: $301-6$.

69. Park YJ, Shin K-H, Park J-G. Risk of gastric cancer in hereditary nonpolyposis colorectal cancer in Korea. Clin Cancer Res 2000; 6: 2994-8.

70. Jarvinen HJ, Aarnio M, Mustonen H, Aktan-Collan K, Aaltonen LA, Peltomaki P, De La Chapelle A, Mecklin JP. Controlled 15. year trial on screening for colorectal cancer in families with hereditary nonpolyposis colorectal cancer. Gastroenterology 2000; 118 : 829-34

71. Watson P, Lin KM, Rodriguez-Bigas MA, Smyrk T, Lemon S, Shashidharan M, Franklin B, Karr B, Thorson A, Lynch HT. Colorectal carcinoma survival among hereditary nonpolyposis colorectal cancer family members. Cancer 1998; 83: 259-66.

72. Smyrk TC, Watson P, Kaul K, Lynch HT. Tumor-infiltrating lymphocytes are a marker for microsatellite instability in colorectal cancer. Cancer 2001; 91: 2417-22.
73. Collins FS. Shattuck Lecture - Medical and societal consequences of the Human Genome Project. N Engl J Med 1999; $341: 28-37$.

74. David KL, Steiner-Grossman P. The potential use of tumor registry data in the recognition and prevention of hereditary and familial cancer. NY State J Med 1991; 91: 150-2.

75. Lynch HT. Cancer and the family history trail. NY State J Med 1991; 91: 145-7.

76. Houlston RS, Collins A, Slack J, Morton NE. Dominant genes for colorectal cancer are not rare. Ann Hum Genet 1992; 56: 99-103.

77. Ramsey SD, Clarke L, Etzioni R, Higashi M, Berry K, Urban N. Cost-effectiveness of microsatellite instability screening as a method for detecting hereditary nonpolyposis colorectal cancer. Ann Intern Med 2001; 135: 577-88.

78. Reyes CM, Allen BA, Terdiman JP, Wilson LS. Comparison of selection strategies for genetic testing of patients with hereditary nonpolyposis colorectal carcinoma: effectiveness and costeffectiveness. Cancer 2002; 95: 1848-56.

79. Sankila R, Aaltonen LA, Jarvinen HJ, Mecklin J-P. Better survival rates in patients with $\mathrm{MLH} 1$-associated hereditary colorectal cancer. Gastroenterology 1996; 110: 682-7.

80. Gryfe R, Kim H, Hsieh ET, Aronson MD, Holowaty EJ, Bull SB, Redston M, Gallinger S. Tumor microsatellite instability and clinical outcome in young patients with colorectal cancer. $\mathrm{N}$ Engl J Med 2000; 342: 69-77.

81. Branch P, Bicknell DC, Bowan A, Bodmer WF, Karran P. Immune surveillance in colorectal carcinoma. Nature Genet 1995; 9: $231-2$.

82. Jass JR, Cottier DS, Jeevaratnam P, Pokos V, Browett PJ. Pathology of hereditary nonpolyposis colorectal cancer with clinical and molecular genetic correlations. In: Baba S, editor. New Strategies for Treatment of Hereditary Colorectal Cancer. Tokyo: Churchill Livingstone, 1996: 29-39.

83. Boman BM, Fry RD, Curran W, Deborah R, Cocker T, Kovatich A, Barusevicius A, Palazzo J, Cuesta K, Anne P, Melchert L, Fishel R, Mitchell E. Unique immunohistochemical features of MSI-classified tumors from HNPCC patients. Proceedings of ASCO 1999; 18: 236 a (Abstract).

Funding Support: This article was supported by revenue from Nebraska cigarette taxes awarded to Creighton University by the Nebraska Department of Health and Human Services. Its contents are solely the responsibility of the authors and do not necessarily represent the official views of the State of Nebraska or the Nebraska Department of Health and Human Services. Funding was also received through NIH Grant number 1 U01 CA86389-01 and EC Grant number QLRI-CT-1999-00063. 